STUDI

FRANCESI

\section{Studi Francesi}

Rivista quadrimestrale fondata da Franco Simone

180 (LX | III) | 2016

Varia

\title{
Jacques T.E. Thomas, Autour de la belle Heaumière, sur quelques vers du Testament Villon
}

\section{Martina Crosio}

\section{(2) OpenEdition}

Journals

\section{Édition électronique}

URL : http://journals.openedition.org/studifrancesi/5263

DOI : 10.4000/studifrancesi.5263

ISSN : 2421-5856

Éditeur

Rosenberg \& Sellier

\section{Édition imprimée}

Date de publication : 1 décembre 2016

Pagination : 510

ISSN : 0039-2944

\section{Référence électronique}

Martina Crosio, « Jacques T.E. Thomas, Autour de la belle Heaumière, sur quelques vers du Testament Villon », Studi Francesi [En ligne], 180 (LX | III) | 2016, mis en ligne le 01 janvier 2017, consulté le 18 septembre 2020. URL : http://journals.openedition.org/studifrancesi/5263 ; DOI : https://doi.org/ 10.4000/studifrancesi.5263

Ce document a été généré automatiquement le 18 septembre 2020.

\section{(c)}

Studi Francesi è distribuita con Licenza Creative Commons Attribuzione - Non commerciale - Non opere derivate 4.0 Internazionale. 


\title{
Jacques T.E. Thomas, Autour de la belle Heaumière, sur quelques vers du Testament Villon
}

\author{
Martina Crosio
}

\section{RÉFÉRENCE}

JACQUES T.E. THOMAS, Autour de la belle Heaumière, sur quelques vers du Testament Villon, «Romania», 531-532, tome 133/3-4, 2015, pp. 446-469.

1 J.T.E. Thomas consacre son analyse au passage du Testament de François Villon bien connu sous le titre apocryphe de Regrets de la belle Heaumière: quelques strophes dans lesquelles une vieille femme de plaisir déplore le temps qui passe et se plaint de la vieillesse survenue. Par une étude linguistique minutieuse et approfondie, l'A. parvient à proposer une nouvelle interprétation de ces huitains. Sa lecture bien argumentée, grâce à laquelle ces strophes acquièrent un sens en parfait accord avec le contexte ironique et les connotations grivoises de l'œuvre villonienne, a également le mérite d'éclairer d'un jour nouveau non seulement l'épisode de la belle qui fut heaulmiere, mais aussi l'ensemble des vers qui l'encadrent. 